\title{
MicroRNA-769-5p Promotes the Growth of Glioma Cells by Targeting Lysine Methyltransferase 2A [Corrigendum]
}

Chang M, Yan P, Zhang B, et al. Onco Targets Ther. 2019;12:9177-9187.

The authors have advised that the affiliation list on page 9177 is incorrect. The correct affiliation list is:

${ }^{1}$ Department of Neurology, Xi'an No.3 Hospital of Northwest University, Xi'an 710069, People's Republic of China; ${ }^{2}$ Department of Neurology, The Affiliated Hospital of Northwest University, Xi'an 710021, People's Republic of China; ${ }^{3}$ The College of Life
Sciences, Northwest University, Xi'an 710069, People's Republic of China; ${ }^{4}$ Department of Neurology, The First Affiliated Hospital of Xi'an Medical University, Xi'an 710077, People's Republic of China; ${ }^{5}$ Department of Pathology, Xi'an No.3 Hospital of Northwest University, Xi'an 710069, People's Republic of China; ${ }^{6}$ Department of Pathology, Xi'an Central Hospital, Xi'an 71000, People's Republic of China

The authors apologize for this error.

\section{Publish your work in this journal}

OncoTargets and Therapy is an international, peer-reviewed, open access journal focusing on the pathological basis of all cancers, potential targets for therapy and treatment protocols employed to improve the management of cancer patients. The journal also focuses on the impact of management programs and new therapeutic agents and protocols on patient perspectives such as quality of life, adherence and satisfaction. The manuscript management system is completely online and includes a very quick and fair peer-review system, which is all easy to use. Visit http://www.dovepress.com/ testimonials.php to read real quotes from published authors. 